\title{
Consistency and Coherence of Turtle Conservation Policies in Venu Island Wildlife Sanctuary, Kaimana, West Papua
}

\section{Zeth Parinding $^{1}$, Sambas Basuni ${ }^{2}$, Herry Purnomo ${ }^{3}$, Nandy Kosmaryandi ${ }^{4}$, Yusli Wardiatno ${ }^{5}$}

${ }^{1 *}$ Graduate School of Bogor Agricultural University, Dramaga main Road, Campus IPB Dramaga, Bogor, Indonesia 16680 ${ }^{2}$ Department of Forest Conservation and Ecotourism, Faculty of Forestry, Bogor Agricultural University, Academic RingRoad, Campus IPB Dramaga, Bogor, Indonesia 16680

${ }^{3}$ Department of Forest Management, Faculty of Forestry, Bogor Agricultural University, Academic RingRoad, Campus IPB Dramaga, Bogor, Indonesia 16680

\section{Received July 28, 2016/Accepted November 18, 2016}

\begin{abstract}
Policy management of turtle conservation in the region of Venu Island Wildlife Sanctuary, Kaimana, West Papua is indispensable. Therefore, this study aimed at examining the turtle conservation policy and it's implementation, both the consistency and coherence. The analytical method used is content analysis and simple mathematic statistics. The consistency of turtle conservation management policies is found inconsistent in implementation. Similarly, coherence between the policy on turtle conservation management with government policy is found incoherent, as it is more oriented to "economic growth" compared to turtle conservation management. This is due to weak management, among others: communication, resources, attitudes and behavior, and bureaucratic structures. "Management Authority Multi-stakeholder" was found as a form of the collaborative approach in carrying out the turtle conservation among institutional managers with other key stakeholders. Consolidation of these institutions need to be carried out by non-governmental organizations, i.e. Conservation International (Indonesia) Corridor Kaimana and local government, i.e. the Department of Marine and Fisheries, Department of tourism and culture along with Indigenous Peoples. So policy integration among sectors as well as the consistency and coherence should be coherent in the approach to building synergy with policies of sustainable management of turtle conservation in the region of Venu Island Wildlife Sanctuary, Kaimana, West Papua.
\end{abstract}

Keywords: management authority multi-stakeholder, policy, turtle conservation, Venu Island Wildlife Sanctuary

*Correspondence author, email: zethpar@yahoo.co.id,ph.: +62-81398936672

\section{Introduction}

The area of Venu Island Wildlife Sanctuary (VIWS) is an area of turtle conservation located in Kaimana, West Papua, as declared in Decree of Level II Regional Head of Fakfak Number 503/1204 of 1991 and Decree of the Minister of Forestry Number SK 783/ Menhut-II/2014. The area has not been delineated along the $62.456 \mathrm{~km}$. Kaimana is a division of Fakfak district in 2002. The district has Area of Venu Island Wildlife Refuge. It is comprised of 16,320 hectares (Wahjono et al. 1992), an area that has been identified as core areas (core habitats) for the population of some species of turtles, i.e: green turtle, hawksbill, and olive ridley turtles (Parinding 2010). This watery area is a core zone for other types of marine biota (Regional Regulation Number 4 of 2014). In 2011, the leatherback turtle was found stranded and died on the beach Kaimana (Parinding 2011). The area of turtle conservation needs to be supported by policies on the management of turtle conservation, among others, Minister of Forestry Regulation Number 57/ Menhut-II/ 2008, and the
Strategy and Action Plan for Turtles Conservation (draft). The potential capacity building of turtle conservation managers (Center for Conservation of Natural Resources of West Papua), among other things: 1) The area has high biodiversity and in the region of world's coral triangle (UNPPKK 2005, 2007; Huffard et al. 2010; 2012), 2) The available human resources, science, and technology, collaboration and shared learning. While its conservation policy, i.e: legislation related to biodiversity (ecosystems, species, genetic). Institutional policy manager must be capable of integration, coordination, and collaboration) in mutual learning. The policy is expected to be able to manage human resources, science, and technology in coping with accelerating changes in the management of natural resources and surroundings along with population growth. Policies are needed to support mutual learning on innovation, environmental economics, and policy analysis, as an instrument of integration policy (Green et al. 2012; Rogge \& 
Reichardt 2013; 2015; Reichardt \& Rogge 2014).

Policies related to species conservation is being prepared, including Strategic and Action Plan on Conservation (SAPC) of Turtles (draft) in Ministry of Environment and Forestry. The Turtle SAPC does not accommodate turtle conservation management in Kaimana. Medium Term Development Plan of Kaimana does not provide management of turtle conservation there. This is one threat to the sustainability of sea turtle populations and habitats in Kaimana district (UNPPKK 2007; 2005). Inconsistent and incoherent policies and their implementation on a turtle conservation need to be examined in this study. The policy needs to be studied, i.e: Regulation of the Minister of Forestry Number 57/Menhut-II/2008, Turtle SAPC, and the Medium Term Development Plan of Kaimana district.

Problems of policy strategy in creating a model of adaptive management of turtle conservation in the region of VIWS, Kaimana, West Papua is legal certainty and integration. The consistency and coherence policies require communication, knowledge of resource use, attitudes and behavior that is consistent and flexible bureaucratic structures. Furthermore, the consistency of policies relating to turtle conservation is needed among the central government, and the turtle conservation policy coherence between the central government and local governments, and among sector agencies. Additionally, comitment among stakeholders takes into consideration to understand the mindset, behavior, and course of action among them. The consistency and coherence are parameters in evaluating the policy and its implementation, and also policy between the policy (Portella \& Raube 2011). On the other hand, the effectiveness of a policy is often associated with the consistency and coherence of the (Barry et al. 2010). The legal certainty consisting of: law and traditional or customary rules. Policies considered either in its manufacture or implementation is measured by consistency and coherence.

Consistency in the context of the policy is the extent of conformity between the creator and the executor of a policy that has been defined and implemented. Whereas, the context of policy coherence (Noor 2013) is a synergy between policies (Van Bommel \& Kuindersma 2008; Norton 2005), and the suitability of the policies (Portella \& Raube 2011; 2012); Antikarov 2011). Consistency and coherence of a policy are reviewed to minimize conflict (Lu \& Sun 2011) as an effort to increase the effectiveness of natural resources management. Therefore, this parameter is used to evaluate both policy and implementation as well as inter-relation policies. On the other hand, legal pluralism should be encouraged in the management and conservation of species of turtle conservation in the respective area. This is an attempt to accommodate the rules of indigenous/ traditional utilization and adaptive management of natural resources as long as they live and breed.

This study aims at assessing the consistency of the turtle conservation policies of the Minister of Forestry Regulation Number 57/ Menhut-II/2008 as well as its application. Strategic and Action Plan on Conservation (SAPC) of Turtle and it's turtle conservation policy. Coherence between Turtle SAPC with the Medium Term Development Plan of Kaimana district is related to the conservation of sea turtles in the region of Venu Island Wildlife Sanctuary, Kaimana, West Papua.

Methods

Description of the study site This study was conducted in both the municipality of Sorong and Kaimana District, West Papua. Implementation of the study took place in April 2014.

Tools and materials Study tools used in this study, among others: simple mathematics, and computer units. While the research material used in this study, i.e: a map of the study location. Both data and information on turtle conservation policies are obtained from documents variety. The contents of each of these documents is a material that will be processed and analyzed. The documents examined, i.e: Regulation of the Minister of Forestry Number 57/MenhutII/2008, SPAC of Turtle, and the Medium-Term Development Plan (MTDP) in Kaimana district.

Data collection technique This study data (Table 1) from the Center for Conservation of Nature Resources of West Papua, House of Representatives Kaimana, and Government of Kaimana (The Department of Marine Fisheries Kaimana, Department of Tourism and Culture Kaimana, Department of Transportation and so Shipping Nusantara Indonesia (SNI), and Owners of customary rights "petuanan" tribe of Koiway (clan Samai, Laturaw, Seningraw, Aituaraw).

Data analysis The information and data were analyzed using content analysis to measure the consistency of policies and its coherence (Busch et al. 2005; Duraiappah \& Bhardwaj 2007). Content analysis was conducted to examine the consistency of the policies and its implementation, and examine the coherence between the policy with other policy. A consistency of policies is analyzed to examine the "gap" or gaps (Nathan 2005; Antikarov 2011) between the suitability of policies/rules (related to the theory, legislation and legitimacy) with its policy implementation. A consistency of policies that analyzed was descriptive. Whereas the simple mathematics is done based on the review of policy coherence between SAPC of Turtle with MTDP in Kaimana district. This study uses document of Turtle SAPC unassigned (draft) because it is still under discussion by the Ministry of Forestry (Ministry of Environment and Forestry) and its relevant stakeholders. Content analysis in examining the policy coherence can be divided into 2 categories, such as conceptual, and relational. This study examines based on the conceptual. This conceptual examine is to calculate the frequency of occurrence of a concept (phrase) enter the 2 documents of policies. Each subsequent step using this analysis (Busch et al. 2005; Duraiappah \& Bhardwaj 2007). Concept (phrase) which analyzed the matters related to the objectives, instruments or decisions to achieve the objectives (programs and activities), along with stakeholder (actor/actors) related turtle conservation

If the frequency of concept has been obtained, the values will be incorporated into the matrix of policy coherence. The Normalization is necessary to design a table that already exists, which aims to systematically minimize redundancy (repetition) and ensure the integrity of data and the data 
Table2 Analysis of the rights, responsibility, and stakeholder returns

\begin{tabular}{llll}
\hline \multicolumn{1}{c}{ Stakeholder } & \multicolumn{1}{c}{ Rights } & \multicolumn{1}{c}{ Responsibility } \\
\hline The Center for & Granting of & Submit copies of SIMAKSI to relevant & Everyone who moves in within the region \\
Conservation of Natural & SIMAKSI & agencies & can be monitored properly \\
Resources of West & & &
\end{tabular}

Papua

The Departement of Marine and Fisheries

Granting of Permit for Fishing
The Department of

Tourism and Culture

Kaimana

The Department of
Transportation and
Shipping Nusantara
Indonesia (Pelni)
Owners of customary
rights "petuanan"
Koiway tribe (clan
Samairauw, Laturauw,
Seningrauw, Aituarauw)

Granting of Permit for Eco-Tourism

Granting of
permission passes
through in the
region of VIWS
Utilization of
livelihood, such as
sea cucumbers, and
Trochus niloticus

Granting permission based on quotas issued by the competent authority and located outsi de the "multi-function block" in VIWS area that enclosed with the blocking map

Submit copies of License to relevant agencies

\section{Granting eco -tourism permission only on the tourist block, and religion against the shrine/old Koiway rate ("multi-function block")}

Granting permission cruise ship traffic
Exploiting the potential of the sea does not enter the "multi-function block" and does not exceed the carrying capacity of the region

Licensing incurred will be monitored along with other parties

Tourism activities do not enter the protected block in the region of SMPV

Provides revenue from the tourism sector Cruise ship traffic do not throw garbage in the sea around the region of SMPV
Granting permission for capture of marine life, such as sea cucumbers, Trochus niloticus in the traditional block ("multi -function block") of VIWS area
The number of biotas that be used and sales locations reported
Fulfillment the needs of indigenous/traditional people

Modification from Sembiring et al. 2010

dependencies. Normalization is done by avoiding 3 Data Anomaly: Update, Insertion and Deletion Anomaly. Furthermore, it is normalized by using the following Equation [1]:

$$
N_{i j}=n_{i j} / n_{i j} *
$$

Note: Skor $\mathrm{Nij}=$ Rated frequency after normalization, $\mathrm{nij}=$ Frequency of certain concepts in the policy (A policy on B policy), nij* = the highest frequency value that appears in all cells.

After normalization, the degree of coherence (Dk) of each pair is a policy calculated simply by the mathematical equation as Equation [ 2 ]:

$$
\left.\mathrm{Dk}=\sum \mathrm{i} \sum \mathrm{j}(1-\text { Score } \mathrm{Nij}) \text {, and } 0 \leq \mathrm{Score} \mathrm{Nij} \leq 1\right)
$$

The degree of coherence (Dk) is calculated based on the total sum of the values of each row and columns into the cell. The policy coherence matrix indicates how many concepts (in the form of phrases) mentioned in item (time) of a policy text contained in the text of other policies, or vice versa. In the same way, also, the numbers of each row and column summed. After that, the amount of each policy concept is divided by the greatest concept of these policies. Furthermore, additional rows and columns are added on Policy Coherence Matrix (PCM). The sum of values in rows or columns indicate the degree of coherence of the total phase of every policy debate.

\section{Result and Discussion}

Consistency between policy and its implementation Regulation of the Minister of Forestry Number P.57/MenhutII/2008 on Tutorial Strategy and national Species Conservation 2008-2018 (Table 2) as a turtle conservation policy in the execution of turtle conservation management in the area of Venu Island Wildlife Sanctuary (VIWS), Kaimana, West Papua which was found inconsistent. This is due to Conservation Strategy and Action Plan on Conservation (SAPC) of turtle that has been developed since 2010 as its derivative regulation has not been set. On the other hand, this rule has not a combined system which is applicable based consensus/local rules. It is thought to be a cause of threat for turtle population sustainability and habitat that is still going on, including in the region of VIWS, Kaimana, West Papua. These regulations need to be established as a national action strategy on species conservation of endangered species and they are given a very high priority to 
Table 2 The policies of turtle conservation and its implementation in the region Venu Island Wildlife Sanctuary area, Kaimana, West Papua

\begin{tabular}{|c|c|}
\hline The policies & Implemented \\
\hline Minister Regulation of & Coordination between stakeholders is still weak. \\
\hline Forestry Number & Agencies turtle conservation managers respond less well to report problems occurred. \\
\hline P.57/Menhut-II/2008 on & The local government has not made a turtle conservation as a reference in formulating regional development. \\
\hline the guideline for Strategi & Strategy and Action Plan of turtle conservation nationally unassigned. \\
\hline and Conservation on & The absence of facilities for local governments to develop strategies for turtle conservation in the region. \\
\hline Species National & There are no incentives for local governments to implement turtle conservation in the region. \\
\hline \multirow[t]{2}{*}{$2008-2018$} & The patrol activities tentatively and sustainable related to the conservation areas most near, i.e: Kumawa \\
\hline & Mountains Nature Reserve. \\
\hline Decree of Level II & The turtle conservation area has not had its status established spatially. \\
\hline Regional Head of Fakfak & The management plan of turtle conservation has not been accommodated relating to the area status of turtle \\
\hline Number $503 / 1204$ of & conservation has not established. \\
\hline 1991 and Decree of the & Coordination between stakeholder has not been done to respond to and anticipate problems that arise in the \\
\hline Minister of Forestry & conservation area and its surroundings. \\
\hline Number SK & The central government has limited funding for the management of the turtle conservation area. \\
\hline 783/Menhut-II/2014) & Turtle as migrant animals found not only occupy of Venu Island Wildlife Sanctuary area. \\
\hline The Regional Regulation & Protection conducted on marine life including fish group (include turtles) throughout the Regional Waters \\
\hline of Kaimana Number 4 & Conservation Area of Kaimana. \\
\hline Year 2014 on the & The marine area in the region Venu Island Wildlife Sanctuary is a "multi-function block", particularly around \\
\hline Regional Marine & the Island Venu. \\
\hline Conservation Area in & Implementation of SASI/Ngamma management accommodated as traditional use, such as sea cucumbers, \\
\hline \multirow[t]{5}{*}{ Kaimana } & Trochus niloticus, and Turbo marmatus. \\
\hline & Mapping of customary rights "petuanan" to accommodate the proposed ownership by tribes and clans. \\
\hline & "Old graveyard" or "Sacred graveyard" of the tribe Koiway on the island need to be considered in the \\
\hline & management of konservasi penyu in VIW area. \\
\hline & The use of "gillnets" and the compressor is not allowed in the utilization of fish and marine life. \\
\hline
\end{tabular}

preserve. One of the national species conservation is the conservation of sea turtles.

Funding for turtle conservation in VIWS area, Kaimana, West Papua, is considered inadequate to support the activities in monitoring the turtle population that has been done so far. Funding turtle conservation management gained through the management of traditional knowledge (SASI/Nggama), adopt a turtle conservation management, and conservation and environmental management to support the funding sources for the development of Kaimana. In addition, adaptive management of sea turtle conservation, among others: the protection and development of the turtle nesting habitat, banning the use of "trawling/gill net", preventing the destruction of coral reefs and seagrass, empowerment community related to environmentally sound management. Effective management strategies for the management of turtle conservation, including the protection of turtle nesting, limiting fishing technologies and interventions that can reduce the rate of extinction, and provide closure of fisheries catch temporal space for the recovery of the resources available (Benson et al. 2007a, Benson et al 2007b, Bailey 2012, Gjertsen et al. 2012, Tapilatu et al. 2013). Thus, It is necessary policy and implementation, and or policy between the policy, which in its decision-making mechanism is capable of bridging the turtle conservation management.

Therefore, the allocation of funds from both local governments as well as from NGOs as conservation international Indonesia corridor Kaimana (CII-CK) is outlined in the form of a memorandum of understanding (MOU). The MOU was done in regards to backup of Kaimana marine conservation area (KMCA) and supported by the regional regulation (RegionalReg) Number Kaimana 4 Year 2014. While the technical implementation unit (TIU) center for conservation of natural resources of West Papua (CCNRWP), division chief of staff manokwari region II, Region IV Kaimana Conservation section, is the central government as an extension of the authority of the Ministry of Forestry c.q. directorate of forest protection and nature conservation (now Directorate of Conservation of Natural Resources and Ecosystems) as a turtle conservation management institution. funding is allocated only to fund patrol in the area of kumawa mountains nature reserve (Kaimana district) and in the area of fakfak mountains natural reserve (Fakfak). The activities are to be done 3 times a year with the funding of each period of IDR16,000,000.

In-depth interviews concerning turtle conservation management institutions, i.e: CCNRWP, shows that there has been no allocation of funds for turtle conservation in the area of Venu Island Wildlife Sanctuary. It is due to the fact that this respective area of conservation is not a priority (area of existing stipulation) for the management of conservation area in West Papua, including the turtle conservation itself. Therefore, "the shared-secretariat" of the CCNRWP, 


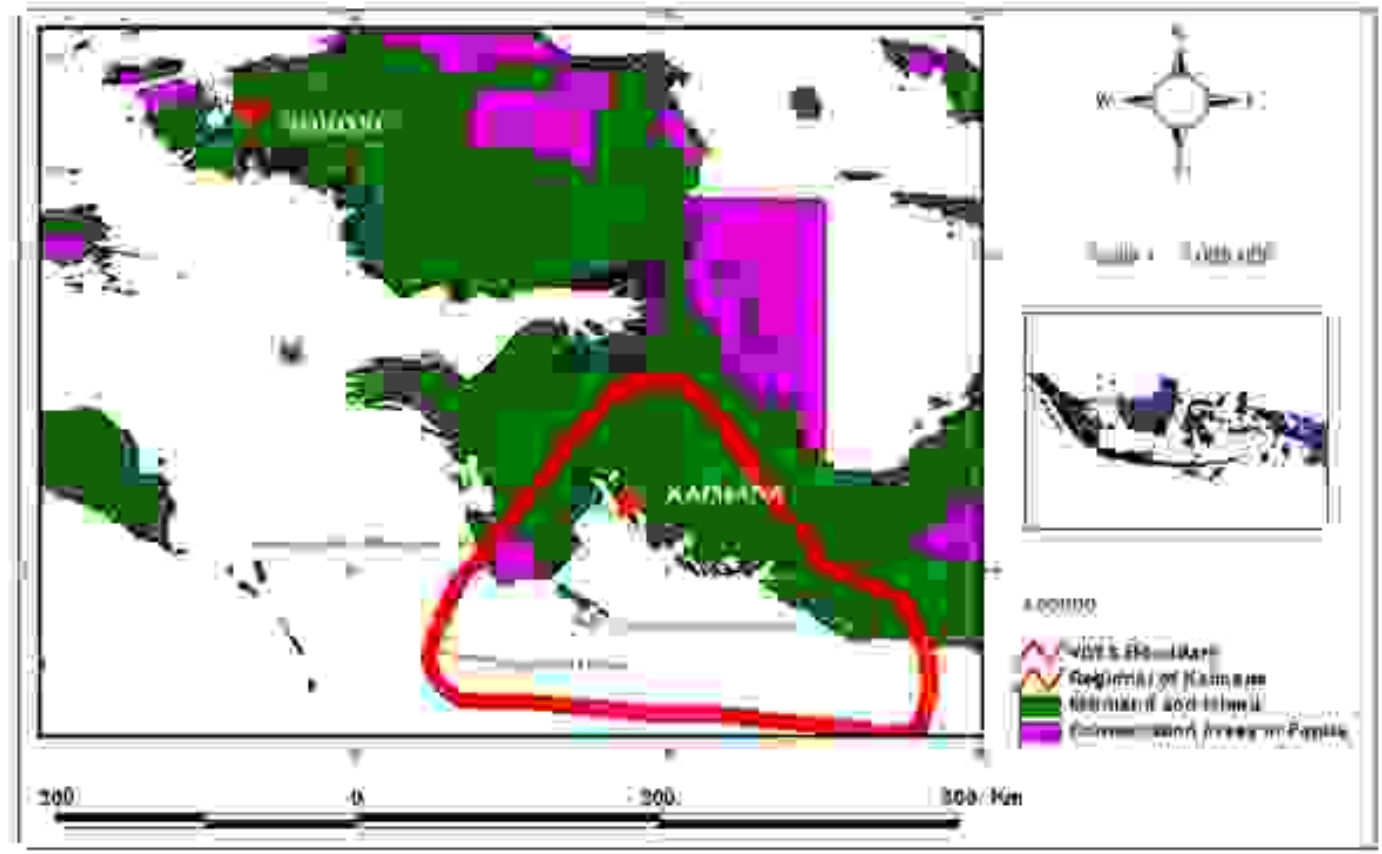

Figure 1 Mapping of "petuanan" of the tribe Koiway based on clans in the district Buruway, Kaimana, West Papua.

Department of Marine and Fisheries Kaimana, NGOs CIICK, and representative of customary rights of tribal Koiway" has supported the implementation turtle population monitoring since 2009-2014.

Decree of Second-Level Regional Head (Regent) of Fakfak in 1991 is a policy for reviewing area of Turtle Natural Reserve and surrounding areas, and the Decree of the Ministry of Forestry in 2014 as a policy for the appointment of protecting the area of the provincial jungle of Papua and West Papua. The area of Venu Island Wildlife Sanctuary has become a part of the forest areas protection. The process of setting the area of VIWS as an area of turtle conservation has gone backward. The weakness progressed through, among others, is the lack of coordination among stakeholders in anticipating turtle conservation management, yet has the Turtle Conservation Management Plan, for the central government has limited funding.

Kaimana Regional Regulation Number 4 Year 2014 is the policy that governs the provisioning area of KMCA in Kaimana. Area of VIWS has wider waters of its land, mostly located in the KMCA. The water area of the core zone made KMCA. On the other hand, SASI/Ngamma Management in the traditional use by indigenous peoples, such as cucumbers, Lola/Trochus niloticus, and Turbo marmoratus. Therefore the mapping of customary rights called "petuanan" in the area of VIWS should be regulated in regard to controlling the state over the "ownership" of local tribes and clans. Distribution of ethnic groups residing in the Kaimana District is a cultural kinship bird's head of Papua (Figure 1). The area of VIWS also at customary rights (petuanan) Koiway Tribes in the area of Buruway with each Clan (Figure 2). "Ownership" on area of VIWS is Koiway tribe led by clan Aituraw as a representative of the King Commission, and clans (Seninggrauw, Samairauw, and Latuarauw). On the other hand, the area of VIWS found their "old graveyard" or relatives to the Koiway Tribe, turtles are often caught up in the "gillnets" and the use of compressors in the utilization of marine organisms, as well as cruise ship traffic.

The problems in managing the conversion of this turtle are weak coordination among organizational/institutional parties related to the conservation of sea turtles. Lack of coordination prior to the year 2009 has led to degradation of turtle populations. In 2011 the fourth stakeholder-initiated in forming "shared-secretariat", for monitoring the turtle population. The results of joint activities indicate that green turtle nesting population trends increased (Figure 3). Other problems in implementing the conservation of turtles in turtle conservation Area of VIWS is not used as a priority for both central and local government. This suggests the presence of inconsistencies in the implementation of its policies. Most of the stakeholders have not made the turtle conservation efforts, as a priority to support economic development.

On the other side of the waters around area of VIWS found to also contain oil and potential gas. On the one hand, this is the area of VIWS traffic Bryde's whales, and dolphins. Furthermore, enforcement of law is powerless relating to the collection of marine life, especially sea cucumber. This is done merely using custom rules (the role of use). As for legal sanctions, i.e. compensation in cash or building homes based on the sale value of the fishing results. Depth interviews for information relating to sales T. niloticus and T. marmoratus, is done without permission (illegal). Transportation uses fishing vessels with the ultimate goal of Surabaya. On the other hand, their illegal poaching activities for flying fish eggs around the VIWS water area of Collaboration requires a commitment by learning together under the authority, roles, 
Table 2 Type of planning, drafter, evaluator, and certifier of planning documents in Perum Perhutani

\begin{tabular}{|c|c|c|c|c|}
\hline Working unit & Type of planning & Drafter & Evaluator & Certifier \\
\hline \multirow[t]{6}{*}{$\begin{array}{l}\text { Board of } \\
\text { directors }\end{array}$} & RUP & Board of Directors & BOD \& Supervisory Board & $\begin{array}{c}\text { Ministry of Environment } \\
\text { and Forestry }\end{array}$ \\
\hline & RJP & Board of Directors & BOD \& Supervisory Board & $\begin{array}{c}\text { Minstry of State -owned } \\
\text { Enterprises }\end{array}$ \\
\hline & RKL & Board of Directors & BOD \& Supervisory Board & $\begin{array}{l}\text { Ministry of Environment } \\
\text { and Forestry }\end{array}$ \\
\hline & RKT & Board of Directors & BOD \& Supervisory Board & $\begin{array}{l}\text { Ministry of Environment } \\
\text { and Forestry }\end{array}$ \\
\hline & RKAP & Board of Directors & BOD \& Supervisory Board & $\begin{array}{c}\text { Minstry of State -owned } \\
\text { Enterprises }\end{array}$ \\
\hline & RO & $\begin{array}{c}\text { President Director/Head of } \\
\text { Agency/KSPI }\end{array}$ & RKAP Team & Director of Finance \\
\hline \multirow{6}{*}{$\begin{array}{l}\text { Regional } \\
\text { division }\end{array}$} & RUP & Head of Regional Division & Head of PP & President Director \\
\hline & RJP & Head of Regional Division & Head of PP & President Director \\
\hline & RKL & Head of Regional Division & $\begin{array}{c}\text { Head of Forestry } \\
\text { Department of Province }\end{array}$ & Governor \\
\hline & RKT & Head of Regional Division & $\begin{array}{l}\text { Head of Forestry } \\
\text { Department of Province }\end{array}$ & Director of Finance \\
\hline & RKAP & Head of Regional Division & Head of PP & Director of Finance \\
\hline & RO & Bureau Chiefs & Head of PP & Head of Regional Division \\
\hline \multirow[t]{6}{*}{$\mathrm{KPH}$} & RPHL/RPKH & Head of Planning Section & Head of Planning Bureau & Head of Regional Division \\
\hline & RJP & Head of KPH & Head of Planning Bureau & Head of Regional Division \\
\hline & RTT & Head of KPH & Head of Planning Section & Head of Regional Division \\
\hline & RKT & Head of KPH & Head of Planning Section & Head of Regional Division \\
\hline & RKAP & Head of KPH & Head of Planning Bureau & Head of Regional Division \\
\hline & RO & $\begin{array}{l}\text { Section Chief of Forest } \\
\text { Management }\end{array}$ & Vice Chief of KPH & Head of KPH \\
\hline
\end{tabular}

and functions, as well as responsibilities of each stakeholder (Table 2).

The study reveals a lack of coherence between turtle SAPC with MTDP of Kaimana District as local warlords. The lack of coherence is caused by a double approach or a different orientation between the sea turtle conservation plan and the regional development plan. The construction area is more focused on "economic growth", rather than conservation management, such case can boost economic growth. It is seen by various statements about what programs and activities such as increased production and plantation forestry, forestry and fisheries, and mining and energy. On the one hand, local development is oriented to aquaculture and tourism.

Based on this analysis, MTDP of Kaimana District already accommodates the principle of conservation of the environment, but it does not accommodate the context of turtle conservation in local development plans. It is to be scrutinized, due to increased production of capture fisheries, forestry and plantation, exploration and exploitation, mining and others can result in problems that are no longer environmentally friendly to the conservation of sea turtles. This could potentially increase the conflict of interest in the utilization of natural resources. This entails the integration of policies that are able to combine economic development framed by turtle conservation in area of VIWS, Kaimana, West Papua.

World Conservation Union based on IUCN, categorizes all types of turtles in the world as endangered species (IUCN 2006 in Webb 2008). Turtles are classified into sea reptiles that immigrate and can survive very long (Stacey et al. 2012a, 2012b), for coastal communities across Indonesia have an ecological role. The role of the interest sub-system, economic and cultural is also important (Harteti et al. 2014 Karman 2008; Harteti 2013; Harteti et al. 2014). Therefore, the management of mega-fauna takes into account social, cultural, economic context, and the wider political relating to operations performed in its management (Champbell 2010). The success of turtle conservation requires the existence of good supports by stakeholders on policy, among other things: legal certainty, communication within the network, and incentives. Legal certainty is correlated to both formal and non-formal formal laws (customs rules/agreements). Communication in the network at both national and international levels deals with financing incentives and awards as a trade off. Action research on turtle conservation should be implemented more systematically and focused through a derivative policy. The derivative action research is a SAPC of turtles. The turtle SAPC includes, among others: general policy, the necessary conservation measures, targets to be achieved in the next year, and stakeholders, have a common goal at turtle conservation management. On the other hand, turtle conservation measures require the allocation of the funds obtained from the central and local governments and other funding sources.

Appointment area of VIWS, Kaimana, West Papua is a part of forest protection area based on the Minister of Forestry Degree Number SK 783/MENHUT-II/2014. Appointment area of VIWS is based on the value of distinctiveness/uniqueness area devoted to the protection of 


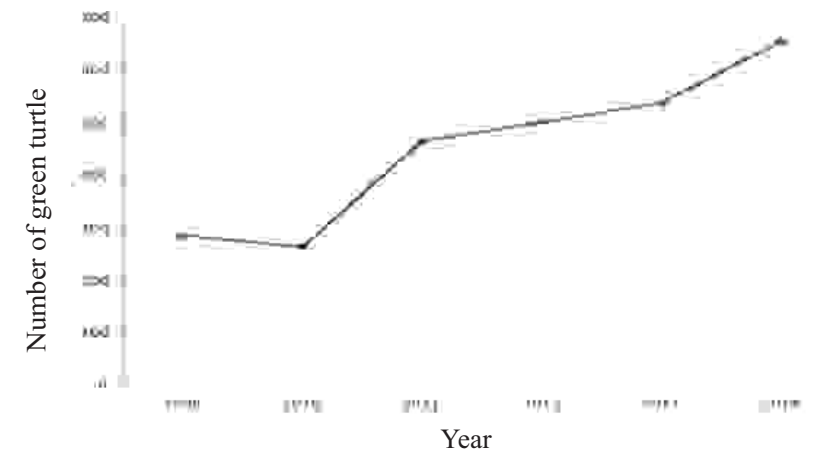

Figure 2 The development of green turtles nesting of 2009-2014 in the region Venu Island Wildlife Sanctuary, Kaimana, West Papua.

the population and nesting habitat (Wahyono et al. 1992). On the other hand, the exist od publish activities through their customary/traditional is interacting in the area of VIWS. Such interactions are not only related to the utilization of natural resources but also to the emotional as original ethnic of Koiway region. While the phenomenon of adaptive management over the Area of VIWS concerns the turtle conservation in the absence of an agreement as money turtle conservation management efforts involving partners (indigenous/traditional and local stakeholders).

Management of turtle conservation in the area of VIWS, Kaimana, West Papua, has not been carried out effectively and efficiently in the adaptive management of turtle conservation. During this time, the consistency and coherence of the policy are not accommodated turtle conservation management. Turtle conservation policy, relating to these arrangements, for the welfare of the surrounding community in a sustainable manner. This is due to the absence of mutually supporting policies integrated into good management of the central government and local government. Integration policy in cooperating the area of VIWS, is accommodated in the Ministerial Regulation Number 85/Menhut-II/2014 on procedures for cooperation in nature reserve area (NRA) and nature preservation area (NPA). Policy consistency in the management of natural resources is determined in, among others: the perception of stakeholders and regional government (Harahap et al. 2015) as well as public awareness (Hasani 2012). Besides that, other policies related to sea turtle populations and their habitats can support policy integration in the sustainability of sea turtle conservation and environmental conditions in Area of VIWS. The policy will be needed to improve the system of natural resources management, and the condition of the coastal environment (Cicin- Sain \& Knecht 1998), and integration policies (Pomeroy 2012). Therefore, the management of VIWS area is expected not only for the protection of turtle ecosystems concerning both population and habitat, but also their cultural connectedness with the management of biodiversity and its application of the law effectively. The integration of natural resource management systems required the existences of their connectedness with the local cultural studies, and management using the application of the law or with another effective way (Portman etal. 2012).

The management of VIWS area has been done to conserve turtle populations and their habitats, but have not been accommodated in the welfare of society as a revenue management system part of the ecosystem. Management area of turtle conservation does not yet have a formal document about management plan and block division management in determining the priority of management. Therefore, this case is found not only in the management of turtle conservation in the area of VIWS. In general, the implementation of policies in the management of natural resources carried out by the member states, developing countries, have not reached the target management yet (Makinde 2005).

Management of turtle conservation in area of VIWS was carried out because of legal certainty in establishing communication as coordination, support resource management, attitude and behavior of each stakeholder as a commitment in co-management, and bureaucratic structures which were not flexible in shared learning. Communication between stakeholders as a factor essence (core) for the implementation of policy and co-ordination in the management of turtle conservation is crucial in the area of VIWS. Resources to be treated with the knowledge are wisdom in their implementation and limitations caused by lack of budget allocation (of funds). It makes no consistent implementation of the policy of every stakeholder involved in the management. An attitude in regard to the commitments reflects a positive mental attitude. This can cause inconsistency in influencing the behavior that is consistent with this attitude, as the commitment of the stakeholders is responsible for implementation to the success of a good policy. On the other side, law enforcement shows their attitude and inaction of the law enforcement agencies as well as local government administrators, for violations and crimes against the management of natural resource conservation. The area of VIWS is determined by consideration of the peculiarities of the region and the use of which has long conducted local community. The bureaucratic structure is one inhibiting factor in the realization of strategic guidelines and turtle conservation plans. The central government through the Ministry of Forestry (Ministry of Environment and Forestry) has a moral responsibility for the sustainability of sea turtle conservation in the area of VIWS and Kaimana District who allegedly have 4 species of turtles (green turtles, hawksbill, olive ridley turtles, and leatherbacks), as mandated in the Ministry Regulation of Forestry Number P.57/Menhut-II/2008, and Turtle SAPC (draft). The implementation of policies that are inconsistent because of the bad condition (Edwards1980), i.e: communication, resources, attitudes, and bureaucratic structure. On the other side, this aspect requires clear definitions relating to the competence and role together based on a hierarchical structure that allows minimizing conflict within institutional coordination (Portela \& Raube 2011).

"Shared-sectarian/ad hoc committee" is needed as the process of establishing a forum for collaboration in the management of turtle conservation. The role of collaboration is needed in the management of natural resources (Purnomo 
et al. 2014a; 2014b). The initial stages of the process of collaboration in the management of turtle conservation in the area of VIWS are strengthening turtle conservation management institution (CCNRWP institution) as the embodiment of "management authority multi-stakeholders". The agency serves to connect the management institutions and other key stakeholders. The next stage of CCNRWP consolidation together with non-government organizations (CII-CK) and local governments (Departement of Marine and Fisheries of Kaimana, and the Department of Tourism and Culture of Kaimana). Their role is to conduct collaborative approach in the management of turtle conservation in the area of VIWS, Kaimana, West Papua. On the other hand, they need to do the identification of the growing issues, in the form of work programs and activities of the international turtle conservation manager. Terms to be a member of secretariat of the "forum" before "management authority multi-stakeholders" must have integrity and professionalism (the independent), which is not a better member of the institutional managers and other key stakeholders. "Management authority multi-stakeholders" become part of the institutional structure of the manager as container integrity of turtle conservation and management policies. The secretariat has the ability to facilitate meetings, to provide administrative services, to prepare materials coordination, to distribute, and to publish agreement results to the stakeholders concerned. The secretariat operational costs can be obtained from the institutional managers, other key stakeholders, and the other legitimate funding sources.

Action research on the turtle conservation in the area of VIWS, Kaimana, West Papua, shows that the management institution requires a collaborative approach with other relevant stakeholders. The coherence of the 2 policies can provide space for the management of turtle conservation in Kaimana. On the other hand, the policy coherence can accommodate the establishment of institutions of sharedmanagement flexible as a collaborative approach to turtlebased management. "Management authority multistakeholders" is one solution to its management, which can do the negotiation process by involving stakeholders in decision-making and development agreements. Management institution in the management of natural resources can make negotiation process involving all relevant stakeholders (Sembiring et al. 2010), and also decision-making in the development agreement (Borrini 1996). "Management Authority Multi-stakeholder" requiring the model and protocol negotiation mechanisms must be built first based on the location of the implementation. Mechanism model and negotiation protocol requires:

1 Emphasis on the interests and needs, not on the positions or facts.

2 More persuasive than the opposition.

3 Has commitment as the foundation of the collective agreement than dispute resolution.

4 Constructive communication (de Nooy 2013) to develop collective learning rather than negative criticism and strengthen the arguments of each party.

5 The achievement of long-term settlement of disputes because each party has the common commitment.
6 The use and exchange of constructive information.

7 Have the high-level facility.

Consistency and coherence in the management of turtle conservation policies require the participation of stakeholders starting from planning, action, monitoring, and reflection/evaluation based on defined objectives or strategies. Natural resource management approaches imply the participation of stakeholders in the planning stage, actions, monitoring, and reflection/evaluation (Waterman et al. 2001). Consistency and coherence management policy on turtle conservation requires a collective learning in management actions (functions of study, policy development and implementation, political limitations in the design representation, and limited funding), accommodate changes (knowledge of the biophysical, legal, institutions and regulations or social consideration) in improving its management. It requires the turtle conservation adaptive management as a systematic and reliable approach in learning, both outcomes, and feedback in his causal loop. Adaptive management is one of the natural resource management in a systematic and reliable approach to learning outcomes and feedback from management actions, accommodating change and improving management (Walters 1986; Purnomo \& Mendoza 2011; Purnomo 2012). The adaptive management is an act of the beginning of the party's involvement in the continuous learning process by turtle conservation managers. Implementation activities can not be separated from the functions of research (Bormann et al. 2007), and the regulatory/policies (Purnomo et al. 2009; Williams 2011).

The consistency and coherence of this policy need to be integrated into building a model of adaptive management in the Area of turtle conservation VIWS. Criteria required (William 2011), among other things are stakeholder involvement and support, the ability to reach resource management objectives, the assessment and monitoring information, consistent implementation with applicable law.

As for the involvement of stakeholders in the integration phase, include ability to actively involve in local activities, identify the key information, identify existing and potential leaders, garner the support of local leaders, collect data, identify problems and needs, assess the existing organization, initially form local groups.

So the adaptive management of community-based turtle conservation makes the role and presence of stakeholders are:

1 Opportunities for local communities to evaluate their own resources based on their own early experiences.

2 Local community becomes a major part of making plans and decisions.

3 The local communities become a major player in the implementation.

4 Local communities have stronger role in decisionmaking and implementation process.

Adaptive management policies on the area of VIWS turtle conservation is in need of an integrated coastal management. This is necessary as the coastal management system to address human behavior and protect the functional integrity of both land and marine ecosystems. It is aimed at achieving sustainable development in a coastal region. 
Policy coherence between turtle conservation with other policies Policy coherence (Table 3 ) among Kaimana MTDP with Turtle SAPC was found 156 times their concept (in the form of a phrase) on the objectives, instruments/procedures, and actors. While policy coherence between Turtle SAPC with Kaimana MTDP found 491 times their concept. The degree of policy coherence (Table 4) among the policies being compared results in 0.7 . This shows that the percentage of coherence between the policy is $70 \%$, and the percentage of non-coherency is $30 \%$. Non-coherency worth $30 \%$ of the policy is the contribution of Turtle SAPC. As for the ranking values (columns and rows) is 2 , indicating that the turtle SAPC is not represented as a whole in its medium Kaimana district. Thus, regional development of Kaimana district has not considered the turtle conservation as an important issue that can provide social welfare. Therefore, the policy of Kaimana MTDP to Turtle SAPC has shown that the Kaimana regional development based solely on the concept of "environmental preservation". So Kaimana regional development yet has specific concepts related to "turtle conservation" or "protection of turtle population and its habitat".

This study shows that there is a coherent policy between Turtle SAPC in the water area. This is due to the different approaches between turtle conservation plans and the local development plan. Kaimana government is more oriented to "economic growth" rather than to the turtle conservation. On the other hand, Kaimana government also drew attention to "environmental preservation", in the form of Kaimana area of water conservation and socialization activities on the environment. Kaimana local governments have not paid serious attention to the turtle conservation management guidelines established due to the strategy and action plan for the conservation of sea turtles as a reference. On the one hand, the area of VIWS has not been designated/special set. It is still the appointment of provincial forest protection of the area. On the one hand, the area of VIWS has potential conflicts in its management concerning interested stakeholders, prior to the appointment of the area. This entails negotiation and collaboration among stakeholders with consistent care and commitment, in regard to turtle conservation and sustainable economic development in Kaimana district. On the one hand, the existence of turtles provides one indicator of a healthy local water condition. On the other hand, this may affect biodiversity, both in quantity and quality of fish and marine life. Such conditions help their subsistence of Kaimana community (e.g.: an increase in people's income and meet protein requirements, etc.).

Both of these policies have not accommodated community rules on local/traditional developed in the community in the use of turtle eggs and body, as well as how many people are taking, how long retrieval time, and for what requirement. The results showed that taking turtles eggs and body parts is done to meet the needs of protein, public revenues, build and repair houses, and send children to school. Income communities at least every 2 weeks instead of 2 people who took the turtle eggs and body parts, each of which can get the sale price IDR $1,000,000$. The selling price of turtle eggs is IDR5,000. Turtle egg collection leaves 25 eggs per nest (not allowed to take everything).

Things that need to be communicated in collaboration with co-operation in NRA and NPA based on the Area of cooperation Ministerial Regulation Number 85/MenhutII/2014 is the cooperation regulation in NRA and NPA. Legal certainty about the appointment of the Area of turtle conservation can combine economic development with a turtle conservation oriented to block division management is based on ecological distinctiveness turtle habitat, and traditional use is made public with the prevailing system.

Policy coherence between Turtle SAPC and Kaimana MTDP in the future need to pay attention to the sea turtle conservation policy integration with the local community/traditional as the primary basis within the framework of the analysis. It is necessary to consider the things that can be accommodated due to chain termination incomes. The analytical framework should consider strategies to respond to the growing population of sea turtles and their habitats, the practical aspects of the turtle conservation policy, adaptation and development, and security resources. Implementation of the policy on special designation Area of (turtle conservation management) needs their guidance on the practical implementation of integration policy coherence of turtle conservation management in the

Table 3 The matrix on the coherence of policies based on how much (time) concept of a policy text contained in the text of other policies

\begin{tabular}{lcc}
\hline & SAPC of Turtle & MTDP in Kaimana \\
\hline SAPC of Turtle & - & 156 \\
MTDP in Kaimana & 491 & - \\
\hline * SAPC of Turtle: Strategy and Action Plan for Conservation of Turtle (draft), MTDP in Kaimana: Medium-Term Development Plan in Kaimana
\end{tabular}

Table 4 The degree of coherence between policies based on numerical calculations

\begin{tabular}{lcccc}
\hline & SAPC of Turtle & MTDP in Kaimana & Total line & Ranking line \\
\hline SAPC of Turtle & - & 0.7 & 0.7 & $\underline{2}$ \\
MTDP in Kaimana & 0.0 & - & 0.0 & 1 \\
\hline Total column & 0.0 & 0.7 & $\underline{0.7}$ \\
\hline Ranking column & 1 & $\underline{2}$ & & \\
\hline
\end{tabular}

*SAPC of Turtle: Strategy and Action Plan for Conservation of Turtle (draft) MTDP, in Kaimana: Medium-Term Development Plan in Kaimana 
face of changes in ecosystem management and policies. Integration of policy changes in natural resource management is used to improve the policy coherence and minimize the governance of multi-level (van Bommel \& Kuindersma 2009). Assessment incoherent policies need to be done as a prevention effort in building models of adaptive management of turtle conservation in area of VIWS, Kaimana, West Papua. This was done as a prevention effort related to a major reform of the management institutions and policies between the main stakeholders. Special policies are needed as the integration efforts of cooperation among stakeholders, i.e: cooperation between the state, an inter-governmental organization or agency heterogeneous cosmopolitan. Policy coherence is needed in order to go beyond coordination between governments.

\section{Conclusion}

Problems consistency and policy coherence in the adaptive management of turtle conservation in the area of VIWS, Kaimana, West Papua, among other things: 1) consistency and coherence of the policy is not accommodated the management of SASI/NGGAMA of the tribe Koiway and sacred tomb; 2) Consistency and coherence policy is not to provide management block in the protection and development for habitat of adaptive management of sea turtle conservation; 3 ) the consistency and coherence of the policy did not facilitate the management of natural resources (adoption by the turtle management), communications and networking, changing behavior and attitudes of human resources, and bureaucratic structures are flexible (e.g. "Authority Multistakeholder"), and 4) this encourages the strengthening of institutions managing turtle conservation, the Center for Conservation of Natural Resources of West Papua. Consolidation of these institutions is required as sectoral integration together with the Agency of the Regional Development Planning and the Environment, and the Department of Forestry and Fisheries, along with Conservation International Indonesia-Corridor Kaimana. In addition, the Department of Tourism Culture and it's indigenous/traditional should involve.

\section{References}

[AEG] Aspen Environment Group. 2009. Policy consistency and plan amandements: Tehachapi renewable transmission project. http://ftp.cpuc.ca.gov/gopherdata/environ/tehachapi-renewables/FINALPolicyALL.pdf. [March 4, 2013].

[UNPPKK] Universitas Negeri Papua (UNIPA) dan Pemerintah Kabupaten Kaimana. 2005. Atlas Sumberdaya Pesisir Kawasan Kabupaten Kaimana. Manokwari: Universitas Negeri Papua.

[UNPPKK] Universitas Negeri Papua dan Pemerintah Kabupaten Kaimana. 2007. Penyusunan Tata Ruang Wilayah Pesisir dan Pulau-Pulau Kecil serta Rupa Bumi Kabupaten Kaimana Propinsi Papua Barat. Manokwari: Universitas Negeri Papua.

Antikarov V. 2011. Hedging policy consistency theory vs pravtice: the role of management's expectations in the implementation of hedging policy. Enterprise Risk Management Symposium Society of Actuaries, March 14-16, 2011.

Bormann BT, Haynes RW, Martin JR. 2007. Adaptive management of forest ecosystems: did some rubber hit the road? Bioscience 57:186-191. https://doi.org/10.16 41/B570213.

Borrini-Feyerabend, G. 1996. Collaborative management of protectedaAreas: Tailoring the approach to the context. Gland, Switzerland: Issues in Social Policy, IUCN.

Busch C, de Maret PS, Flynn T, Kellum R, Le S, Meyers B, Saunders M, White R, Palmquist M. 2005. Content Analysis. Corolado: State University Departement of English. http://writing.colostate.edu/guides/research/ content/. [Oktober 19, 2012].

Champbell LM. 2010. Studying sea turtle conservation and learning about the world: insights from social science. Conservation and Society 8(1):1-4. https://doi.org/10. 4103/0972-4923.62671.

de Nooy W. 2013. Communication in natural resources management: Agreement between and disagreement within stakeholder groups. Ecology and Society 18(2):44-55. https://doi.org/10.5751/ES-05648180244.

Duraiappah AK, Bhardwaj A. 2007. Measuring Policy Coherence Among The MEAs and MDGs. [July 1, 2011]. http://www.iisd.org.

Green A, White A, Tanzer J. 2012. Integrating fisheries, biodiversity, and climate change objectives into marine protected area network design in the coral triangle. Jakarta: The Nature Conservancy for the Coral Triangle Support Partnership.

Guenette S, Alder J. 2007. Lessons from marine protected areas and integrated ocean management initiatives in Canada. Coastal Management 35:51-78. https://doi.org/ 10.1080/10/1080/08920750600970578.

Harahap IM, Fahrudin A, Wardiatno Y. 2015. Pengelolaan kolaboratif kawasan konservasi penyu Pangumbahan Kabupaten Sukabumi. Jurnal Ilmu Pertanian Indonesia 20(1):39-46.

Harteti S, Basuni S, Mas'yud B, Yulianda F. 2014. Role of stakeholder in the management of Pangumbahan turtle conservation area. Jurnal Analisis Kebijakan Kehutanan $11(1): 104-121$.

Harteti S. 2013. Peningkatan kinerja konservasi penyu melalui strategi pengelolaan konservasi. [dissertation]. Bogor: Bogor Agricultural University.

Hasani Q. 2012. Konservasi sumber daya perikanan berbasis masyarakat, implementasi nilai luhur budaya Indonesia dalam pengelolaan sumber daya alam. Aquasains 
1(1):12-20.

Huffard CL, Wilson J, Hitipeuw C, Rotinsulu C, Mengubhai S, Erdmann M, Adnyana W, Barber P, Manuputty J, Mondong M, Purba G, Rhodes K, Toha H. 2012. Pengelolaan berbasis ekosistem di bentang laut kepala burung Indonesia: Mengubah ilmu pengetahuan menjadi tindakan. Jakarta: The Nature Conservancy.

Huffard CL, Erdmann MV, Gunawan T. 2010. Defining Geographic Priorities for Marine Biodiversity Conservation in Indonesia. Jakarta: Coral Triangle Support Partnership.

Lowry GK, White AT, Christie P. 2009. Scaling up to networks of marine protected areas in the Philippines: Biophysical, legal, institutional, and social considerations. Coastal Management 37:274-290. https://doi.org/1080/08920750902851146.

Lu N, Sun YH. 2011. Population biability analysis and conservation of Chinese Grouse Bonasa Sewerzowi in Lianhuashan Nature Reserve, North-West China. Bird Conservation International 21:49-58. https://doi.org/ 10.1017/S0959270910000183.

Noor IY. 2013. Re-desain konservasi pesut Mahakam (Orcaella brevirostris Gray, 1866) berbasis perubahan sebaran di sungai Mahakam, Kalimantan Timur [dissertasi]. Bogor: Bogor Agricultural University.

Parinding Z. 2011. Monitoring, Pendataan, dan Pembuatan Sarana Pembesaran Tukik Kerjasama CI Program Kaimana, Seksi KSDA IV Kaimana, dan Masyarakat Adat. Sorong: Buletin Kepala Burung Balai Besar Konservasi Sumber Daya Alam Papua Barat.

Parinding Z. 2010. Suaka Margasatwa Laut (SML) Pulau Venu. Sorong: Buletin Kepala Burung Balai Besar Konservasi Sumber Daya Alam Papua Barat.

Portela C, Raube K. 2011. Coherence in EU foreign policy: What kind of polity? Vol. 68. Leuven Centre for Global Governance Studies. [June 6, 2011].

Portela C, Raube K. 2012. The EU polity and foreign policy coherence. Journal of Contemporary European Research 8(1):3-20.

Purnomo H, Yasmi Y, Prabhu R, Yuliani L, Priyadi H, Vanclay JK. 2003. Multi-agent simulations of alternative scenarios of collaborative forest management. SmallScale Forest Economics, Management and Policy 2(2):277-292.

Purnomo H, Achdiawan R, Melati, Irawati RH, Sulthon, Shantiko B, Wardell A. 2014. Value-chain dynamics: streangthening the institution of small-scale furniture producers to improve their value addition. Forests, Trees and Livelihoods 1-15. https://doi.org/10.1080/14728 028.2013.875279.

Reichardt K, Rogge K. 2014. How the policy mix and its consistency impact innovation: Findings from company case studies on offshore wind in Germany. Working Paper Sustainability and Innovation, 1-41. http://hdl.handle.net/10419/97266.

Rietig K. 2012. Climate policy integration beyong principled priority: A framework for analysis. Working Paper No. 99, Centre for Climate Change Economics and Policy. http://www.cccep.ac.uk.

Rogge KS, Reichardt K. 2015. Going instrument interactions: Towards a more comprehensive policy mix conceptualization for environmental technological change. SPRU Working Paper Series (SWPS) 1-47.

Sembiring E, Basuni S, Soekmadi R. 2010. Resolusi konflik pengelolaan Taman Nasional Teluk Cenderawasih di Kabupaten Teluk Wondama. Jurnal Manajemen Hutan Tropika 16(2):84-91.

Stacey NE, GJ Van Der Kraak, KH Olsen. 2012a. Male primer andorine responses to peovulatory female cyrininds under natural conditions in Sweden. Journal of Fish Biology 80(1):147-165. https://doi.org/10.1111/ j.1095-8649.2011.03162.x.

Stacey NE, Johanna K, Mark GM, Samuel P, Jotham N. 2012 b. Prospects for whale shark conservation in Eastern Indonesia through Bajo traditional ecological knowledge and community-based monitoring. Conservation and Society 10(1):63-75. https://doi.org/10.4103/09724923.92197.

Sugiyono. 2012. Metode Penelitian Administrasi. Bandung: PenerbitAlfabeta.

van Bommel S, Kuindersma W. 2009. Policy integration, coherence and governance in Ducth climate policy: A multi-level analysis of mitigation and adaptation pplicy. Wageninngen, Alterra, Ducth: Alterra-rapport, $122 \mathrm{hlm}$.

van Bommel S, Kuindersma W. 2008. Policy integration, coherence and governance in Dutch climate policy: A multi-level analysis of mitigation and adaptation policy. Wageningen, Alterra: Alterra-rapport 1799.

Wahjono T, Bambang W, Sada E. 1992. Laporan Potensi Sumber Daya Alam Laut dalam Rangka Penetapan Kawasan Konservasi Laut di Kepulauan Venu dan Sekitarnya Propinsi Irian Jaya. Bogor: Proyek Pengembangan Kawasan Pelestarian Laut, Direktorat Pelestarian Alam, Direktorat Jenderal Perlindungan Hutan dan Pelestarian Alam, Departemen Kehutanan.

Walters CJ. 1986. Adaptive Management of Renewable Resources. New York: Macmillan Publishing Co.

Webb GJW. 2008. The dilemma of accuracy in IUCN red list categories, as exemplified by hawksbill turtles Eretmochelys imbricata in the IUCN Red List of threatened species: Assesing its utility and value. Endagered Species Research 12hlm. https://doi.org/10. 3354/esr00124. 